\title{
Tonnage Tax Selection as a Means of Overcoming Economic Growth Problems
}

\author{
Bahar Berberoğlu
}

\begin{abstract}
Generally, all the countries have economic growth problems despite the growth in the world economy and globalization today. Low annual Real Gross Domestic Product (Real GDP) increases and insufficient investment rates are the most important problems. As a result of the growth in the world economy, the volume (tonnage) of foreign trade and marine transportation is continuously increasing. Many countries select the Tonnage Tax, which is a special tax regime, to develop the marine transportation sector with the purpose of increasing the insufficient growth and investment rates because of the strong positive relation between the tonnage demand of the countries and the economic growth rates. In our study, we therefore investigated the tax selections of 31 countries for marine transportation. We have chosen the Logit Model as the most significant of the models, which we formed by using the annual Real GDP increases and investment rates, according to the classification percentages. Thus, we have discovered that the countries without insufficient economic growth and investment rates don't feel the need to select the tonnage tax regime, but the countries with such problems use the tonnage tax.
\end{abstract}

Index Terms-Tonnage tax regime, growth rate in real gross domestic product, logit model.

\section{INTRODUCTION}

Although the globalization propensities in the world economy and accordingly the increase in international trade volume, generally all the countries worldwide, except for some, have to struggle with many other economic and social problems besides the issues related to the economic growth. Undoubtedly, the reason behind the importance given primarily to the economic growth problems results from the consideration that the economic growth will simplify the resolution of the other economic and social problems.

As known, the low level of the annual economic growth rates and the insufficiency in the fixed capital formation, or in other words in investments come on top of the problems with respect to the economic growth. It is clear that the resolution of many other economic and social problems will be simplified with the increase in the annual economic growth rate and the annual investment rate in a country. Here, the fact that production and trade are gaining an international dimension day by day also draws attention. Due to this fact, many countries encounter the problem of growing foreign trade deficit.

Therefore, we concentrated on the Tonnage Tax in our study, which is a special taxing regime widely applied in the

Manuscript received October 8, 2016; revised December 20, 2016.

Bahar Berberoğlu is with the Department of Economic and Administrative Programs, Anadolu University and Open Education Faculty, Eskişehir, Turkey (e-mail: bdirem@anadolu.edu.tr). marine transportation sectors, for overcoming the problem of growing Foreign Trade Deficit together with the problems including the low level of the annual Real GDP increase rate and annual Gross Fixed Capital Formation insufficiency, which come on top of the problems related to the economic growth problems in many countries. These countries are able to enlarge their merchant marine fleets by encouraging the marine transportation sectors by means of the tonnage tax they have selected. Hence, they can increase both their annual economic growth and annual investment rates thanks to the infrastructure and fleet investments made in this sector.

Besides, the countries that select the tonnage tax system can substantially decrease their foreign trade deficits through the freight incomes they obtain from marine transportation, because, as known, almost the whole international trade is performed by sea worldwide, and the freight payments which are rendered to the merchant marine fleets may reach significant levels. While the freight costs paid by the national import or export firms, which have the foreign fleets carry out their marine transportation, are export expenditures, the freight costs of the firms, which have their own fleets conduct this transportation, constitute the export income. As a result, while the development of the marine transportation sector in a country clearly decreases the import expenditures, it increases the export incomes and makes a significant contribution to reducing the foreign trade deficit.

Due to the economic activities that have gained a global characteristic today, the establishments generally in every country can't carry on their production activities themselves from beginning to end. Each producer is obliged to sustain this activity within the international division of labor as a ring of a global supply-demand distribution chain [1]. Because approximately $90 \%$ of the international trade is plied by sea way today [2], the volume (tonnage) of the marine transportation is increasing day by day depending on the growth and globalization in the world economy. Therefore, marine trade bears the specialty of being a fast-growing, dynamic and active sector. This specialty of the marine trade has a distinct importance for our country with a $8.333 \mathrm{~km}$ coastal length, and therefore, determination of the marine problems and taking the necessary precautions have a big significance for the future of the marine trade of our country [3].

The researchers conducted point at a strong and positive relation, which increases in time, between the tonnage demands and economic growth rates of the countries. It is seen that approximately $80 \%$ of the change in the world tonnage demand results from the global economic growth and $20 \%$ from the predicted power factors such as coincidental and bad weather conditions, strikes, stock fluctuation and route change to avoid pirates [4]. Because the 
market of international marine transportation is quite open to competition, it is inevitable for the businesses here to encounter negative competition conditions if the incentives and tax advantages, which are offered them by the countries they belong to, are insufficient. For this reason, the establishments in the aforementioned situation have two options: either to go bankrupt or shift their establishments to countries that provide tax concession. Both of these options create a negative result in terms of the economic welfare of the country that owns the establishment. In this sense, public administrations, which want to protect especially their merchant marine fleets or make their countries one of the important marine transportation centers, have to offer new taxation options to provide income or survival opportunity for the marine transportation establishments [5].

As known, the European Union (EU) supplies a high amount of goods from the Far East and it can reach the Far East only by an uninterrupted but quite far sea route through Northern Europe - Mediterranean Sea and Suez Canal. It can be understood that the marine trade policy of the EU focuses on the Mediterranean Sea. Turkey has the chance to form an alternative route for this product flow as a neighboring country, which is located in the eastern part of the EU. Therefore, the transportation system of the EU is very important for our country. On the other side, the high-volume loads that come over the Trans-Siberia in the North are landed in the Mediterranean and transmitted to the world from there. All the infrastructure formations of the EU and Trans-Siberia focus on the Western Europe and Mediterranean, and when their Land Route and Railway corridors are reviewed, it is remarked that the EU harbors are gate-ways opening to the Mediterranean Sea. And Turkey hasn't been included in this formation yet. Moreover, it is noticed that the EU produce sea-focused alternative solutions such as TRACECA for the load flow over Anatolia. TRACECA is a Black Sea policy of the EU. However, this policy also excludes the characteristics of Anatolia to be a natural bridge. It significantly shortens the Central Asia transportation route. It is a Black Sea and Caspian Sea focused Eurasian Connection Project. It is a project that shifts the load flow towards sea without including the Northern Anatolia Land Route [6].

Our country, which is in the period of integration into the EU, has to plan its important infrastructure investments and attempts by eliminating the regional differences to fulfill the necessary growth conditions. Meanwhile, the marine trade policy, which hasn't been taken into consideration adequately in our country so far, must be reviewed carefully and the tonnage tax, which may cause motivation for the development of our marine trade and merchant marine fleet, appears as a matter which should be examined meticulously. Therefore, we touched primarily upon the significance of the tonnage tax in our study considering the tax regime implementation of the EU in the marine transportation. Afterwards, we evaluated the literature related to this matter and defined the economic variables we used. We analyzed the tax regimes, which 31 countries including Turkey, Iceland, Norway and Hungary besides 27 members of the EU applied as of 2010 to meet the increasing tonnage demands, and their economic growth performances altogether. Our beginning point was to form Dual Logit Model in order to set forth how the economic growth indicators of the aforementioned countries influenced the selection of the tonnage tax regime in marine transportation. For this reason, we firstly formed one-variable logit models with the Real GDP Growth Rate (RGDPGR). Then, we thought about the variable that we needed to add for producing a model and we formed our logit model by selecting the Gross Fixed Capital Formation (Investments) ( $\mathrm{GFCF}(\mathrm{I}))$ as the second variable, which was significant both statistically and economically. Finally, we used the Linear Probability Model (LPM), Constrained Linear Probability Model and Probit Model.

All of our models were statistically significant and supported each other. We assessed the hypotheses and classification percentages related to the models in order to choose the best of these models. We found out that the best model was the Logit model.

8 different statistically significant models were formed in this study. 2 of these were one-variable and 6 were two-variable. If the economic variables we used didn't have an influence on the tonnage tax regime, their coefficients would have been statistically insignificant. So obtainment of significant coefficients in all the 8 different models is not a coincidence. According to 'positive' economists such as Milton Friedman (1953), a theory or hypothesis, accuracy of which hasn't been examined with empirical proofs, isn't counted as a part of the scientific research. If one or two models had been formed, this study could have been quite empirical. However, it mustn't be overlooked that the result or theory which emerges as per these two variables is considerable if the coefficients of 8 models are significant.

\section{TONNAGE TAX REgIME IN THE EUROPEAN UNION PROCEDURE FOR PAPER SUBMISSION}

It is a reality that the international marine transportation, which is the biggest transportation sector of the world, has a serious importance for the EU's economy. Transportation sector comprises $7 \%$ of the EU's GDP, 7\% of the employment, $40 \%$ of the member country investments and $30 \%$ of the energy consumption [1]-[7]. Considering that approximately $90 \%$ of the EU's foreign trade and more than $42 \%$ of the trade between its 25 members are plied by sea way, the strategic, political and economic importance of maritime definitely stands out for the EU's economy and welfare.

While marine transportation, which renders transportation service for all the continents and is a worldwide field of operation, has provided an opportunity for the explicit re-evaluation and organization of the international legal structure and setting while enabling the new-world market to develop and expand.

A global and strategic characteristic of the marine transportation clearly shows the need for the administrative authorities of the EU and its member countries to have an active global political approach. Maritime sector has left behind the protests, which are arranged emotionally and recklessly, and handles the legal changes in the EU and the world scene constructively [8].

Together with the globalization, member countries of the EU have started to implement some taxation regimes with regard to the marine transportation companies. One and the 
most important of these regimes is the 'Tonnage Tax Regime'. Tonnage tax is a type of tax collected over the net tonnage of the operated ship, that is, paid in relation to the load that is directly carried, instead of the normal corporate tax, which is collected over the incomes of the marine transportation establishments. Therefore, this tax isn't linked to the profit or loss of the establishment at issue. While the tonnage tax regime is the only regime applied in the marine transportation in some countries, it is implemented as a different preferable regime in others [5].

In line with the community directives about the state assistance for the maritime sector regarding the development of the EU's maritime, many incentive measures have been taken such as the 'tonnage tax' programs, financial support for the freeways of the seas that amounts to millions of Euros, Marco Polo, Trans-Europe Transportation Networks and Close Road Marine Transportation programs [8].

As it is known, the corporate tax rates are quite high in all the countries; however, the establishments that deal with marine transportation can obtain the advantage of paying much less tax for their incomes, because the applied rate in the tonnage tax is extremely low. Thus, whereas the profitability of the national establishments, which exist in the marine transportation sector of the countries that have selected the tonnage tax regime, increases, new investments rapidly flow into this sector from both inside and outside of the country and make a serious contribution to the economic development of the related country.

Hence, merchant marine fleets of many countries have livened up thanks to the application of the tonnage tax as a preferred regime as well as a solitary or normal tax system in some Far East countries and many countries of the EU [5].

This recovery, which is provided with the implementation of the tonnage tax regime in the merchant marine fleets and marine transportation sectors of the countries, doesn't escape from the notice of the countries that have problems with the economic growth rate (Real GDP Growth Rate) and go through recession in merchant marine fleets. Accordingly, the number of countries which put the tonnage tax regime into practice is increasing day by day. In this way, these countries prefer using the tonnage tax regime as a means to increase their economic growth rates and the volume of their merchant marine fleets.

\section{VARIABLES AND Methods Used In OUR RESEARCH}

We selected two economic variables, first the Growth Rate of the Real GDP which has been used in various similar studies [9]-[13] and second Gross Fixed Capital Formation by regarding the prerequisite that a country must have a high capital accumulation and fixed capital formation to have a say in the international marine transportation:

RGDPGR: Real Gross Domestic Product Growth Rate (\% change as per the previous year): GDP is defined as the amount which is found through the subtraction of the goods and services used for the production from the value of all the goods and services produced, and it is a criterion for the size of the economic activities. For the calculation of the annual increase rate in the GDP volume, evaluation is aimed in concern with the comparisons of the economic development dynamics in time and the economies at different sizes in terms of these dynamics. The GDP with the current prices is assessed with the prices of the previous year to calculate the growth rate of the GDP in terms of the physical volume and the calculated volume changes are expressed as per the level (catena) of the reference year (price). Accordingly, the price movements don't swell the growth rate.

GFCF(I): Gross Fixed Capital Formation (Investments) - With Current Prices (as percentage of the GDP): Gross fixed capital formation includes the net earnings (earnings minus losses) that the settled producers obtain in their fixed physical and non-physical assets. This term covers especially the machines and installations, transportation vehicles, worker lodging (housing) and other buildings [14].

The data of the variables we used in our research are shown in Table I:

TABLE I: COUNTRIES AND VALUES OF RGDPGR AND GFCF(I) VARIABLES

\begin{tabular}{|c|c|c|c|c|c|c|c|}
\hline country & category & RGDPGR & GFCF(I) & country & category & RGDPGR & $\operatorname{GFCF}(\mathrm{I})$ \\
\hline B & 1 & 2.4 & 20.0 & $\mathrm{M}$ & 1 & 2.7 & 17.3 \\
\hline BG & 1 & 0.4 & 22.8 & $\mathrm{NL}$ & 1 & 1.6 & 17.3 \\
\hline $\mathrm{CZ}$ & 0 & 2.5 & 24.5 & A & 0 & 2.1 & 20.5 \\
\hline DK & 1 & 1.6 & 16.9 & PL & 1 & 3.9 & 19.9 \\
\hline $\mathrm{D}$ & 1 & 4.2 & 17.4 & $\mathrm{P}$ & 0 & 1.9 & 19.6 \\
\hline EST & 0 & 3.3 & 19.1 & RO & 0 & -1.1 & 24.7 \\
\hline IRL & 1 & -0.8 & 11.9 & SLO & 1 & 1.2 & 20.1 \\
\hline GR & 1 & $-4.9(p)$ & $17.6(\mathrm{p})$ & SK & 0 & 4.4 & 21.0 \\
\hline $\mathrm{E}$ & 1 & -0.3 & 22.3 & FIN & 1 & 3.3 & 18.9 \\
\hline F & 1 & 1.7 & 19.4 & $\mathrm{~S}$ & 0 & 6.6 & 18.0 \\
\hline I & 1 & 1.8 & 19.6 & GB & 1 & 1.8 & 14.9 \\
\hline CY & 1 & 1.3 & 19.1 & $\mathrm{TR}$ & 0 & 9.0 & 18.9 \\
\hline LV & 1 & -0.9 & 18.2 & IS & 1 & -4.0 & 12.8 \\
\hline LIT & 1 & 1.5 & 16.4 & $\mathrm{~N}$ & 1 & 0.5 & 18.9 \\
\hline $\mathrm{L}$ & 0 & 2.9 & 18.4 & HR & 1 & -1.4 & 20.6 \\
\hline $\mathrm{H}$ & 0 & 1.3 & 18.3 & & & & \\
\hline
\end{tabular}

Source: Category variable was compiled from Elschner C. (2013:209) [15].

For information about Iceland's (IS) tonnage tax application: Official Journal of the European Union, [16].

For information about Hungary's (HR) tonnage tax application: Coric D. (2011), [17].

For information about RGDPGR and GFCF (I) variables: Eurostat, (p): provisional (temporary) [14]. 
Our dependent variable, which we defined in Table I categorically and separates the countries as applying or not applying in terms of the tonnage tax, takes 1 if the countries implement the tonnage tax regime, if not, then 0. RGDPGR and GFCF (I) are our permanent independent variables. In Table I, 2010 data in the Eurostat database were used. Besides, all the data are real and there are no inaccessible, predicted or foreseen data. Temporary data have existed only for Greece since 2008 within the scope of these two variables and realized data.

Our beginning point in the research was to form dual logit model. As known for the logit model, the samples have to be big so that the main mass parameter tests can yield significant results on the basis of sample results. As is known, this method is influenced higher by the small samples as per the least squares method. The Maximum Similarity Estimation method obtains asymptotic normality through big samples. Therefore, high unit number that corresponds to each dependent variable value increases reliability of the estimations. Generally, there must be at least 10 observations against 0 and $1 \mathrm{~s}$ in the dependent variable [18].

While building econometric models the Occam's razor is remarkable. By following Occam's razor, we kept our regression model as simple as possible and explained the behavior of $Y$ 'substantially' with two explanatory variables. Because our theory is not strong enough to suggest for including other variables, so we did not introduce more variables and let $u_{i}$ represent all other variables. Eventually, we did not exclude relevant and important variables just to keep the regression model simple and we considered that the overdetermined models also allows us to compare the multicollinearity problems [19]. In our study, we have 31 observations as 10 times 0 and 21 times 1 in the dependent variable. Thus, we thought regarding the size of our sampling that using more than 2 independent variables in our research might lead to some problems for the reliability of the estimations and used only 2 variables. When we build econometric models is remarkable the Occam's razor. Following Occam's razor, we would like to keep our regression model as simple as possible. If we can explain the behavior of $Y$ 'substantially' with two or three explanatory variables and if our theory is not strong enough to suggest what other variables might be included, why introduce more variables? Let $u_{i}$ represent all other variables. We should not exclude relevant and important variables just to keep the regression model simple. The overdetermined models also allows us to compare the multicollinearity problems [19].

Then, we used Probit, LPM, and Constrained LPM models. However, the distribution of the sample ratios become binomial and the symmetric binomial $(\mathrm{P}=\mathrm{Q})$ approaches the normal distribution while $\mathrm{n}$ approaches infinity when the main mass and samples have two options in these models [18]. In the dataset of our study $n=31$, approximately $p=0.68$ and $q=0.32$. Here, the main mass rate $\mathrm{P}$ isn't known and $\mathrm{p}$ and $q$ values in the sample aren't so close to each other. For this reason, we firstly headed for the Logit Model instead of LPM in our study.

In this study, especially the fact that both LPM and Constrained LPM was used besides the logit and probit models and all the models produced were found statistically significant shows the strength of the selected economic variables (RGDPGR and GFCF (I)) in explaining the tonnage tax regime. Hence, it was examined with many models in this study how important these explanatory variables are for the determination of the preferences related to the tonnage tax regime. As known, the -2LL statistics is a model fit index when it comes to Logit Model. We can interpret the effect of the independent variable added into the model by looking at the -2LL values, that is, comparing the difference between the variables that appear in the concordance. -2LL difference indicates the fit difference between two models [20]. The high correlation between the independent variables is also an important matter. This situation results in the multiple correlation problem between the independent variables. When the standard errors of the variables are less than 2 in the model, nonexistence of a multiple correlation problem may be concluded. In the Logit Model, it is necessary to determine the outlier (marginal) values with respect to the independent variable, because the logit model is quite sensitive to outlier values. This situation may cause an observation, which takes place in a category in reality, to appear in another category of the variable [20].

\section{FINDINGS}

First, One-Variable, then Two-Variable Models were formed in our research. The logit models created with the Real GDP Growth Rate (RGDPGR) - a single explanatory variable - are as follows in Table II.

TABLE II: ONE-VARIABLE (RGDPGR) MODELS

\begin{tabular}{|c|c|c|c|c|}
\hline \multirow{2}{*}{$\begin{array}{l}\text { Models } \\
\text { coefficients }\end{array}$} & \multicolumn{2}{|c|}{ Model I Logit Model } & \multicolumn{2}{|c|}{$\begin{array}{l}\text { Model II Logit Model } \\
\text { (Excluding (Sweden)) }\end{array}$} \\
\hline & $\begin{array}{l}\text { Estimated } \\
\text { coefficients } \\
\text { (s.e.) }\end{array}$ & $\begin{array}{l}\text { P value } \\
\text { (Wald ist.) }\end{array}$ & $\begin{array}{l}\text { Estimated } \\
\text { coefficients } \\
\text { (s.e.) }\end{array}$ & $\begin{array}{l}\text { P value } \\
\text { (Wald } \\
\text { ist.) }\end{array}$ \\
\hline \multirow[t]{2}{*}{ constant } & $1.733^{*}$ & 0.011 & $2.548^{*}$ & 0.008 \\
\hline & $(6.484)$ & $(6.417)$ & $(0.967)$ & (6.935) \\
\hline \multirow[t]{2}{*}{ RGDPGR } & $-0.490 *$ & 0.042 & $-0.759^{*}$ & 0.030 \\
\hline & $(0.241)$ & (4.117) & $(0.350)$ & $(4.693)$ \\
\hline Odds ratios & 5.657 & 0.613 & 12.776 & 0.468 \\
\hline $\mathrm{n}$ & 31 & & 30 & \\
\hline
\end{tabular}

${ }^{*}$ Coefficients are significant at $95 \%$ levels.

According to Model I, RGDPGR decreases the probability of a country's tonnage tax application by $61.3 \%$ considering the Odds ratio $(\operatorname{Exp}(\beta))$. In this Model I, the outlier country was found as Sweden with ZResid=-3.114. Upon the exclusion of Sweden from the sampling, Model II was obtained. As per Model II and again the Odds ratio, RGDPGR decreases the probability of a country's tonnage tax application by $46.8 \%$.Coefficients of Model I and Model II are significant at $0.05 \%$.

Two-Variable Models are the models where RGDPGR and GFCF(I) are independent variables. When RGDPGR was considered as the only independent variable, $-2 \mathrm{LL}=32.246$ was found. After GFCF(I) was added to the model,-2LL = 25.513 was found. The difference in between was 32.246-25.513=6.733. Thus, addition of GFCF (I) to the model caused a decrease in -2LL value by 6.733 . According to the $\chi^{2}$ table, the GFCF(I) variable changed the model 
significantly, because $p=0.00946<0.05$, which corresponds to this value. Therefore, two-variable models constituted the $2^{\text {nd }}$ stage of our research. But it was not only the Logit Models that we produced in this section. We also used LPM, Constrained LPM and Probit Models, which can be alternatives for Logit Models.

In Model $\boldsymbol{V}$ which is seen in Table III, the outlier country was found as Hungary with ZResid= -2.893. Model VI was obtained upon the exclusion of Hungary from the sampling. The Hosmer-Lemeshow test, which groups the estimated possibility values and complies with the $\chi 2$ distribution, can be used for the evaluation of the fit goodness of the Logit Model [21]. As per the Hosmer-Lemeshow Test, the model is concordant when the probability is $p>0.05$, which corresponds to $\chi^{2}$. Considering the Odds ratios in Logit models, it can be stated that RGDPGR decreases the probability of the tonnage tax application with 0.477 by $47.7 \%$ on condition that GFCF (I) remains constant and GFCF (I) decreases the probability of the tonnage tax application with 0.533 by $53.3 \%$ providing that RGDPGR remains constant in Model $\boldsymbol{V}$. On condition that GFCF (I) remains constant, the real GDP growth rate of a country decreases the probability of the tonnage tax application by $36.2 \%$ in Model VI. Similarly, gross fixed capital formation decreases the tonnage tax application probability by $40.6 \%$ providing that RGDPGR remains constant.

TABLE III: LPM, CONSTRAINED LPM, LOGIT AND PROBIT MODELS

\begin{tabular}{|c|c|c|c|c|c|c|c|c|c|c|c|c|}
\hline \multirow{2}{*}{$\begin{array}{l}\text { Mode } \\
\text { ls } \\
\text { Coeff } \\
\text { icient } \\
\text { s }\end{array}$} & \multicolumn{2}{|c|}{$\begin{array}{l}\text { Model III } \\
\text { LPM }\end{array}$} & \multicolumn{2}{|c|}{$\begin{array}{l}\text { Model IV } \\
\text { Constrained } \\
\text { LPM }\end{array}$} & \multicolumn{2}{|c|}{$\begin{array}{l}\text { Model V Logit } \\
\text { Model }\end{array}$} & \multicolumn{2}{|c|}{$\begin{array}{l}\text { Model VI Logit } \\
\text { Model } \\
\text { (Excluding H) }\end{array}$} & \multicolumn{2}{|c|}{$\begin{array}{l}\text { Model VII Probit } \\
\text { Model }\end{array}$} & \multicolumn{2}{|c|}{$\begin{array}{l}\text { Model VIII Probit } \\
\text { Model } \\
\text { (Excluding H) }\end{array}$} \\
\hline & $\begin{array}{l}\text { Estimate } \\
\mathrm{d} \\
\text { Coeffici } \\
\text { ents } \\
\text { (s.e.) }\end{array}$ & $\begin{array}{l}\text { P value } \\
\text { ( Partial } \\
\text { t) }\end{array}$ & $\begin{array}{l}\text { Estimat } \\
\text { ed } \\
\text { Coeffici } \\
\text { ents } \\
\text { (s.e.) }\end{array}$ & $\begin{array}{l}\text { P value } \\
\text { ( Partial } \\
\text { t) }\end{array}$ & $\begin{array}{l}\text { Estimat } \\
\text { ed } \\
\text { Coeffici } \\
\text { ents } \\
\text { (s.e.) }\end{array}$ & $\begin{array}{l}\text { P value } \\
\text { (Wald ) }\end{array}$ & $\begin{array}{l}\text { Estimat } \\
\text { ed } \\
\text { Coeffici } \\
\text { ents } \\
\text { (s.e.) }\end{array}$ & $\begin{array}{l}\text { P value } \\
\text { (Wald) }\end{array}$ & $\begin{array}{l}\text { Estimat } \\
\text { ed } \\
\text { Coeffici } \\
\text { ents } \\
\text { (s.e.) }\end{array}$ & $\begin{array}{l}\text { P value } \\
\text { (Z } \\
\text { statistic } \\
\text { ) }\end{array}$ & $\begin{array}{l}\text { Estimat } \\
\text { ed } \\
\text { Coeffici } \\
\text { ents } \\
\text { (s.e.) }\end{array}$ & $\begin{array}{l}\text { P value } \\
(Z \\
\text { statistic } \\
\text { ) }\end{array}$ \\
\hline$\beta_{0}$ & $\begin{array}{l}1.768^{*} \\
(0.528)\end{array}$ & 3.351 & $\begin{array}{l}2.294^{*} \\
(0.578)\end{array}$ & 3.969 & $\begin{array}{l}14.618^{*} \\
(6.484)\end{array}$ & $\begin{array}{l}0.024 \\
(5.083)\end{array}$ & $\begin{array}{l}20.873 * \\
(9.252)\end{array}$ & $\begin{array}{l}0.024 \\
(5.090)\end{array}$ & $\begin{array}{l}8.575 * \\
(3.566)\end{array}$ & $\begin{array}{l}0.016 \\
(2.405)\end{array}$ & $\begin{array}{l}12.381 * \\
(5.276)\end{array}$ & $\begin{array}{l}0.019 \\
(2.347)\end{array}$ \\
\hline$\beta_{1}$ & $\begin{array}{l}-0.068^{*} \\
(0.029)\end{array}$ & -2.378 & $\begin{array}{l}-0.082^{*} \\
(0.028)\end{array}$ & -2.910 & $\begin{array}{l}-0.741^{*} \\
(0.344)\end{array}$ & $\begin{array}{l}0.037 \\
(4.648)\end{array}$ & $\begin{array}{l}-1.015^{*} \\
(0.477)\end{array}$ & $\begin{array}{l}0.033 \\
(4.528)\end{array}$ & $\begin{array}{l}-0.440^{*} \\
(0.194)\end{array}$ & $\begin{array}{l}0.023 \\
(-2.275)\end{array}$ & $\begin{array}{l}-0.607 * \\
(0.272)\end{array}$ & $\begin{array}{l}0.025 \\
(-2.236)\end{array}$ \\
\hline$\beta_{2}$ & $\begin{array}{l}-0.052^{* *} \\
(0.028)\end{array}$ & -1.859 & $\begin{array}{l}-0.076^{*} \\
(0.031)\end{array}$ & -2.500 & $\begin{array}{l}-0.630^{*} \\
(0.302)\end{array}$ & $\begin{array}{l}0.031 \\
(4.349)\end{array}$ & $\begin{array}{l}-0.901^{*} \\
(0.420)\end{array}$ & $\begin{array}{l}0.032 \\
(4.605)\end{array}$ & $\begin{array}{l}-0.369 * \\
(0.169)\end{array}$ & $\begin{array}{l}0.028 \\
(-2.191)\end{array}$ & $\begin{array}{l}-0.534 * \\
(0.241)\end{array}$ & $\begin{array}{l}0.027 \\
(-2.214)\end{array}$ \\
\hline $\mathrm{n}$ & 31 & & 29 & & 31 & & 30 & & 31 & & 30 & \\
\hline$\chi^{2}$ & - & & - & & $7.041^{\dagger}$ & & $6.632^{\dagger}$ & & $24.236^{\dagger \dagger}$ & & $17.572^{\dagger \dagger}$ & \\
\hline $\mathrm{F}$ & 5.327 & & 40.235 & & - & & - & & - & & - & \\
\hline
\end{tabular}

*Coefficients are significant at $95 \%$ levels.

** Coefficients are significant at $90 \%$ levels.

${ }^{\dagger}$ Models are significant at $95 \%$ levels to Hosmer-Lemeshow Test.

${ }^{\dagger \dagger}$ Models are significant at $95 \%$ levels to Pearson Test.

The correlation value between the RGDPGR and GFCF (I) variables was found as 0.148 . This is not a high correlation value. When it comes to the standard errors of the estimated coefficients in Table III, nonexistence of a multiple correlation problem was concluded, because the standard errors of the variables were less than 2 .

We know that the slope coefficient of an explanatory variable measures the effect on the mean value of the dependent variable against one unit change in the value of that variable in linear regression models. However, attention must be paid to the interpretation of the slope coefficients, because LPM, Logit and Probit models deal with the realization probability of a case. All the explanatory variables take part in the calculation of the probability change in logit and probit models, but only the explanatory variable $\mathrm{j}$ takes part in LPM [19]. Individual significance of the model coefficients and the significance of the model definitely present that the established models are capable of explaining the case at issue. According to Amemiya (1981), there are also approximate relations between the coefficients of the logit and probit models [22]. But we concentrated on the classification success by taking advantage of the discriminant analysis in order to make selection among the significant models we formed here, because the proportional expression of the estimation accuracy depends on a successful classification. In case of the existence of qualitative dependent variables, it is suggested to consider the "Accurate Classification Percentage", which is not an adequately precise criterion, rather than the $\mathrm{R} 2$ determination coefficient [23], [24]. Moreover, the expected values of the dependent variable are specified at the probability level as per the independent variables in Logit and Probit models. These probabilities are used in the classification of the observations [21]. As in the discriminant analysis, using classification tables is more meaningful when the target is the classification success [25], [26]. Expectation categories were formed by assigning 1 when the probabilities were above 0.5 , and if below, then 0 . The same assignment was executed for the expected $\widehat{Y}$ in LPM and Table IV was obtained:

TABLE IV: CLASSIFICATION ACCURACY RATES OF MODELS

\begin{tabular}{rcc}
\hline \hline & $\begin{array}{c}\text { One-Variable } \\
\text { ( RGDPGR ) Models }\end{array}$ & $\begin{array}{c}\text { Classification } \\
\text { Accuracy Rates }\end{array}$ \\
\hline $\begin{array}{r}\text { Model } \\
\boldsymbol{I}\end{array}$ & Logit Model & $71 \%$ \\
\hline
\end{tabular}




\begin{tabular}{|c|c|c|}
\hline $\begin{array}{r}\text { Model } \\
\text { II }\end{array}$ & $\begin{array}{r}\text { Logit Model } \\
\text { (Excluding S ) }\end{array}$ & $73.3 \%$ \\
\hline & $\begin{array}{r}\text { Two-Variable } \\
\text { GDPGR and GFCF (I) ) } \\
\text { Models }\end{array}$ & $\begin{array}{c}\text { Classification } \\
\text { Accuracy Rates }\end{array}$ \\
\hline $\begin{array}{r}\text { Model } \\
\text { III }\end{array}$ & $\begin{array}{r}\text { Linear Probability Model } \\
\text { (LPM) }\end{array}$ & $65.5 \%$ \\
\hline $\begin{array}{r}\text { Model } \\
\text { IV }\end{array}$ & Constrained LPM & $79.3 \%$ \\
\hline $\begin{array}{r}\text { Model } \\
V\end{array}$ & Logit Model & $77.4 \%$ \\
\hline $\begin{array}{r}\text { Model } \\
\text { VI }\end{array}$ & $\begin{array}{r}\text { Logit Model } \\
\text { (Excluding H ) }\end{array}$ & $80 \%$ \\
\hline $\begin{array}{r}\text { Model } \\
\text { VII }\end{array}$ & Probit Model & $77.4 \%$ \\
\hline $\begin{array}{r}\text { Model } \\
\text { VIII }\end{array}$ & $\begin{array}{r}\text { Probit Model } \\
\text { (Excluding H ) }\end{array}$ & $80 \%$ \\
\hline
\end{tabular}

We see the models we formed and their classification successes when we check Table 4 . All the models we formed are statistically significant and the classification successes are pretty high. What is important here is which model is better. We will begin especially from the hypotheses and the superiorities of the models. First of all, we can see that both Logit and Probit Models have a high classification success by $80 \%$ excluding Hungary. Because the estimated probabilities in Logit and Probit models were found very close to each other, we expected that their classification percentages would also be very close to each other. We can mention that the logit model will be preferred when we think about "which model would be favored: Logit or Probit?" in the implementation, because the logit curve has a thicker tail and normal or the probit curve approaches the axes more quickly than the logit, considering the cumulative distribution of the logit and probit models in general [19]. According to Hanushek and Jackson (1977), 'Logistic distribution is quite similar to the $t$ distribution with seven degrees of freedom, and the normal distribution is a $t$ distribution, freedom degree of which is infinite' [27].

After the determination of the fact in Model $\boldsymbol{V}$ that Hungary was an outlier value during the formation of the Logit model, this country was excluded from the sample and Model VI was formed. In this way, the classification success increases from $77.4 \%$ up to $80 \%$. Regarding the significance of the -2LL statistics, we are able to make this interpretation: "Independent variable or variables made a significant contribution to the improvement of the estimated model fit in the intended model." [20], because despite the small sampling, the -2LL difference was found as 6.733 and $p$ $(\mathrm{p}=0.00946<0.05)$, which corresponds to that value, was discovered as statistically significant. Therefore, we can mention that 2-variable 'Model VI is the best model'.

Grounding on the Logit model, the fact that the Odds ratios generally take values less than 1 indicates a negative relation between the dependent and independent variables. As we discuss here, Odds ratio provides ease in case of a research interpretation. If it comes to interpretation, the more the growth rate (RGDPGR) and gross fixed capital formation rate $(\mathrm{GFCF}(\mathrm{I}))$ of a country increase, the more the propensity for the tonnage tax application decreases. As we stated before the growth rate of a country decreases the probability of a country's tonnage tax application by $\mathbf{3 6 . 2 \%}$ on condition that GFCF(I) remains constant. Similarly, gross fixed capital formation decreases the probability of the tonnage tax application by $\mathbf{4 0 . 6 \%}$ providing that RGDPGR remains constant.

\section{CONCLUSION}

All the models and coefficients produced in this model are statistically significant. The classification successes of all the models we produced, except for Model III, are above 70\% and this rate is substantially high in terms of the statistical studies conducted in the field of social sciences. Model VI, which was the Logit Model among the models we formed, was determined as the best model. In the scope of these explanations, the success of all the models produced in our study reveal how much the independent (explanatory) variables that we considered were influential on the explanation of the preference, not coincidentally but actually, related to the tonnage tax application of the countries; since the results which we discovered in our study were obtained through not a single method or model, but the formation of eight different models. The coefficients of the GDP Growth Rate (RGDPGR) and Gross Fixed Capital Formation (Investments) (GFCF(I)) variables were found negative. We can certainly mention relying on the results of these models that the GDP Growth Rate (RGDPGR) and Gross Fixed Capital Formation (Investments) (GFCF(I)) values affect the European countries' implementation of tonnage tax regime through a negative relation.

Depending on the economic results we obtained, it can be said that the countries with pretty high economic growth and investment rates don't feel the need to implement the tonnage tax regime. On the contrary, the countries with low economic growth and investment rates select tonnage tax to increase their economic growth and investment rates by livening up their marine transportation sectors.

These results doubtlessly support the argument we foresaw at the beginning. The countries, which have problems with investment rates besides the insufficiency of the economic growth rate and go through a recession in their merchan marine fleets, prefer using the tonnage tax regime as a means for the purpose of developing the volume of their merchant marine fleets and accordingly marine transportation sectors in order to overcome these problems. Contrarily, the countries which don't have any problems with their economic growth and investment rates and the volume of their merchant marine fleets don't feel the need for selecting the tonnage tax regime.

\section{REFERENCES}

[1] O. Çevik and B. Gülcan, "Environmental sustainability of logistic operations and Marco Polo Program," KMÜ Social and Economic Research Journal, vol. 13, no. 20, pp. 35-44, 2011.

[2] A. Çelikaya, "An examination about tax incentives to marine transportation provided by Turkey," Journal of Public Finance, vol 162, pp. 73-102, 2012a.

[3] İ. Demirbilek, "The effect of convenient flag application on Turkish maritime trade," Social Security Chiefs Association, 2012.

[4] The Platou Report. (2011). [Online]. Available: http://www.platou.com/dnn_site/LinkClick.aspx?fileticket=4pyOacnp ros\%3D\&tabid $=84$

[5] A. Çelikaya, "Tonnage tax regime and its implementation in world countries," Journal of Tax Problems, vol. 226, pp. 119-134, $2007 \mathrm{~b}$.

[6] S. Kuşçu, "The European union transportation policy and its reflection in Turkey," Akademic Sight, vol. 5, no. 9, pp. 77-91, 2011. 
[7] IKV. "Transportation Policy of European Union," Economic Development Foundation, May 9, 2010.

[8] F. Karamitsos, "European union and maritime," Marine \& Commerce, 2005.

[9] Y. Ünsan, M. İnsel, and İ. H. Helvacioğlu, "World marine trade and foresights," in Proc. 6th National Coastal Engineering Symposium, 2007, pp. 426-437.

[10] S. Çevik, "An evaluation of international trends in tax structure and tax systems," TISK Academy, vol. 9, no. 16, pp. 186-206, 2014.

[11] A. Mutlu and M. Çelen, The Place of Indirect and Direct Taxes in Turkish Financial System: Political, Social and Economic Results, Publication No: TÜSİAD-T/2012-10/532, 2012.

[12] M. Çiftçi, "National heterogeneity of labor-capital and international maritime as an indicative sector," "ISSGÜÇ" Industrial Relations and Human Resources Journal, vol. 12, no. 3, pp. 137-158, 2010a.

[13] M. Çiftçi, "Global comparative position of Turkish maritime sector as a national wealth," International Journal of Alanya Faculty of Business, vol. 4, no. 3, pp. 1-9, 2012b.

[14] EUROSTAT of Database. (June 6, 2013). [Online]. Available: http://epp.eurostat.ec.europa.eu/portal/page/portal/eurostat/home/

[15] C. Elschner, "Special tax regimes and the choice of organizationa form: Evidence from the European tonnage taxes," Journal of Public Economics, vol. 97, pp. 206-216, January 2013.

[16] Official Journal of the European Union. (January 7 2013). [Online]. Available: http://eurlex.europa.eu/LexUriServ/LexUriServ.do?uri=OJ:C:2008:09 6:0037:0049:EN:PDF

[17] D. Coric, "The introduction of a tonnage tax regime into the Croatian maritime legislation," Poredbeno Pomorsko Pravo, Prosinac 2011, vol. 50 , no. 165 , pp. $75-89,2011$

[18] N. Orhunbilge, Multivariate Statistical Methods, İstanbul University Publication No. 4942, Faculty of Business Administration Publication No. 286, İstanbul, Turkey, 2010.

[19] D. N. Gujarati, Basic Econometrics, Literatür Publishing, İstanbul, Turkey, 2001.

[20] Ö. Çokluk, "Logistic regression analysis: Concept and application," Educational Sciences: Theory \& Practice, vol. 10, no. 3 pp. 1357-1407, 2010.

[21] D. Murat and E. Ișı̣̆ı̆ıçok, "The Expectations regarding economic and political situation in the election Period of 2007: Bursa practice," in Proc. 8th Turkish Econometrics Statistics Congress, May 24-25, 2007.
[22] T. Amemiya, "Qualitative response model: A survey," Journal of Economic Literature, vol. 19 pp. 481-536, 1981.

[23] J. H. Aldrich and D. N. Forrest, Linear Probability, Logit and Probit Models, California: Sage, 1984.

[24] Y. K. Akın and S. G. Turgan, "Determination of the economic indicators of countries in the European union by statistical techniques," Trakya University Journal of Social Sciences, vol. 10, no. 2, pp. 121-140, 2008

[25] D. W. Hosmer and S. Lemeshow, Applied Logistic Regression, John Wiley and Sons, New York, 2000.

[26] A. Oğuzlar, "Determination of the guilt profiler with logistic regression analysis," Uludağ University Journal of Economics and Administrative Sciences, vol. 19, no. 1, pp. 21-35, 2005 .

[27] E. Hanushek and J. Jackson, Statistical Methods for Social Scientists, Academic Press, New York, 1977.

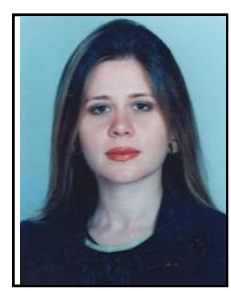

Bahar Berberoğlu was born on March 15, 1973in Eskişehir, Turkey. She graduated with a bachelor of statistics, her research field is in statistics from Anadolu University, Faculty of Science, Department of Statistics in 1994; she postgraduated in the field of statistics from Graduate School of Sciences, Anadolu University in 1998; PhD degree in the field of statistics from Graduate School of Sciences, Anadolu University in 2006.

She is now associate professor in quatitative methods in Anadolu University, Open Education Faculty from 2013.

Her areas of interest are spline methodology, Turkish economic history, Turkish foreign policy, economic crises, European Union, information economy, open and distance education, lifelong learning.

She has published: B. Berberoğlu, "Social capital and lifelong education in the European union and Turkey," International Journal of Business, Humanities and Technology, vol. 6, no. 2, pp. 9-16, 2016.

B. Berberoğlu and C. N. Berberoğlu, "Is Turkey ready for global network in the perspective of European union?" Journal of Statistical Science and Application, vol. 4, no. 9-10, pp. 205-214, October 2016.

B. Berberoğlu, "The analysis of the effects of military coups on gross national product in Turkey: 1950-1984," Romanian Journal of Political Science, PolSci, vol. 16, no. 1, Summer 2016. 